doi: $10.19090 /$ i.2019.30.217-233

ISTRAŽIVANJA

JOURNAL OF HISTORICAL RESEARCHES

30 (2019)
ORIGINAL SCIENTIFIC PAPER

Received: 24 May 2019

Accepted: 14 July 2019

DEJAN D. ANTIĆ

University of Niš, Faculty of Philosophy

dejan.antic@filfak.ni.ac.rs

IVAN M. BECIĆ

Institute for Serbian Culture - Priština, Leposavić

becic89@gmail.com

\title{
MARKET LOAN AND SAVINGS BANK OF VRANJE: 1926-1947
}

\begin{abstract}
The banking system of the Kingdom of Serbia, and later of the Kingdom of Yugoslavia, was principally characterized by numerous small, local money bureaus. These bureaus were founded with the purpose of providing the necessary capital and profit to their shareholders, as well as offering the ground for the capital placement in times of economic depression. The Market Loan and Savings Bank of Vranje was established in the time of a great financial crisis and is thus an example of the money bureau of the aforementioned nature. Moreover, it is the evidence of how the Great Depression affected the private banking system in the Kingdom of Yugoslavia. This paper is based on archival materials and relevant reference materials from both national and international sources.
\end{abstract}

Keywords: The Market Loan and Savings Bank of Vranje, savings deposits, crisis of confidence, moratorium, protection of money bureaus.

\section{Introduction}

$\mathrm{T}$

The banking sector of Serbia started to develop in the second half of the $19^{\text {th }}$ century, or more precisely during the 1880 s, so the number of money bureaus was 179 just before the start of the Balkan Wars. ${ }^{1}$ The expansion of the territory of the Kingdom of Serbia after these wars resulted in the increase of the number of monetary bureaus up to 200 because, alongside the banks founded in 1913 and 1914, the Serbian banking sector included also the banks from Kosovo, Metohija, the region of Raška and Southern Serbia (Macedonia).

As the consequence of the First World War and the three-year-long invasion of Serbia, all the property of the monetary bureaus was largely destroyed and devastated, which meant that their number was significantly smaller after the Great War than it had been in 1919. Besides the Fund Management as the state financial institution and the Privileged National Bank of the Kingdom of Serbia, there remained 45 privately-owned money bureaus in

1 Almanah 1921-1922, volume I, part III - 6. d 125. 
Belgrade and 87 of them in the rest of Serbia. ${ }^{2}$ The total number of private money bureaus was 132 , which indicates that one-third of all the banks existing before the war could not proceed with their normal activities and had to close. Moreover, due to the devastating consequences of the war, a number of money bureaus had to either terminate their business or, owing to the deficiencies in assets, be adjoined to some more successful money bureaus.

\section{Banking Activities after The Great War}

The postwar necessity to restore and rebuild the ruined country meant that numerous money bureaus had to refrain from their primary, banking activities and become investors involved in the business of civil engineering and trade. The period from 1923 onward was characterized by high inflation and acute deficiency of money in order for those money bureaus which had larger funds or which qualified for obtaining advantageous loans from the National Bank of the Kingdom of Serbs, Croats and Slovenes to earn large profits owing to high interest rates and the need to rebuild the ravaged country. In the period from 1919 to 1923 , the National Bank approved loans to the money bureaus that fulfilled the necessary conditions. The loans were granted at a reduced interest rate of $5 \%$, i.e. $6 \%$ from 15 May 1922, and later at $7 \%$ of the Lombard rate. ${ }^{3}$ On the other hand, private money bureaus required the effective interest rate from $7 \%$ to $12 \%,{ }^{4}$ which, amplified by the commission varying from $0.5 \%$ to $1 \%$ per month, led to an increase of the real interest rate for additional $6 \%$ to $12 \%$. Therefore, the interest rate paid by clients varied from the minimum of $13 \%$ to $24 \%$ at most. The comparison of the interest rate required by the banks with the interest rate they paid to the National Bank clearly proves that private banks benefited greatly. It is thus quite logical that money bureaus were the biggest users of loans approved by the central financial institution - out of the total of 1421.2 million dinars of loans in 1922, private banks granted 804.9 million dinars, i.e. their share was $56.64 \%{ }^{5}$

The inflation period could not last indefinitely, which became evident in April of 1922. Up to that moment, the National Bank had approved loans to all institutions interested in credits. However, from April onwards, the National Bank reduced the amount of the approved loans by $10 \%$, which was a short-term measure since there was a great demand for seasonal loans needed for financing export goods, primarily agricultural products. The money market underwent a major change in late December of 1922, when Milan Stojadinović was appointed Minister of Finance. He started the deflation politics with the purpose of strengthening and later stabilizing the value of the dinar. Although the effective money supply was rather low and only 415 dinars per capita in January of 1923, part of the money in circulation was additionally withdrawn. ${ }^{6}$

The financial measures of the new government were followed by the decisions of the National Bank to suspend the approval of new loans at reduced interest rates, to reduce the

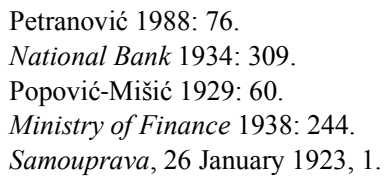


amount of the already approved credits by $10 \%$ and to prolong the period of discount for promissory notes. ${ }^{7}$ The money market was quite stirred by such measures, so numerous money bureaus were forced to close their business or to retreat from the market of the industrial investment credits. This period, which started in January of 1923, was often referred to as the "credit crisis". It was discussed in the Parliament and at political meetings, it was written about in all financial and daily papers: "The credit crisis presupposes panic, general distrust and the withdrawal of capital from the market" ${ }^{8}$ The government financial politics was criticized by the opposing Democratic Party, which was of the opinion that this politics was introduced incompetently. Yet, they acknowledged the decision of the Minister not to yield to promises or threats aimed at printing money. ${ }^{9}$ Stojadinović personally affirmed that the money circulation was decreased from 6 to 5.5 million dinars from October 1923 to May $1924 .^{10}$

The deflation politics and the stable currency resulted in a lower number of financial institutions during 1924. This situation was particularly detrimental to those money bureaus which had engaged their capital in long-term loans granted to the economy, especially industries. The reasons lay in a great demand for credits, which enabled money bureaus to charge extremely high interest rates. The beginning of 1924 was characterized by enormously high interest rates of over $20 \%$ and $30 \%$, even up to $40 \%$. However, the high percentage of interest rates did not facilitate the process of loan approval. ${ }^{11}$ The interest rate is one of the most reliable instruments for evaluating an economy since the more economically developed the state, the lower the interest rate. The SCS Kingdom was peculiar in that the provinces had tremendously different interest rates. The lowest interest rate was in Slovenia, the province with the most advanced economy, while it was considerably higher in Bosnia, Herzegovina and South Serbia.

A drastic change occurred in 1925 when there appeared an excess of money on the market due to business stagnation. The economic situation was reflected in the frequent bank liquidations during the following year, whereas numerous money bureaus fought hard against formal bankruptcy. A certain number of banks collapsed because, among other things, the relationship between their own assets and those of their clients (savings deposits) was extremely negative and indicated very poor liquidity. The value of land, property, buildings, factory investments, various companies and banks shares decreased by almost $30 \%$ during 1926. There were 666 money bureaus in the SCS Kingdom by the end of 1925 in comparison to 651 of them in 1924. However, the number of their branches was in steep decline. Therefore, there were 293 of them in 1925, while this number was 306 just the year before. The number of the money bureau branches was 357 in 1923 and as many as 374 in 1922. The bank shares were also in rapid fall. The shares of the Croatian-Slavonian Mortgage Bank fell from 150 to 55, those of the Yugoslav Bank declined from 170 to 92, while the value of the shares of the First Croatian Savings Bank was reduced from 1,4001,500 to 865 and that of the Croatian Credit Bureau from 170 to $100 .{ }^{12}$

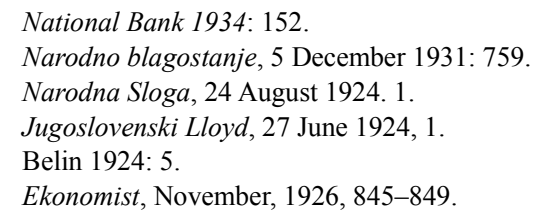




\section{Founding of The Market Loan and Savings Bank of Vranje}

Sixteen banks in Vranje and in its vicinity were founded since the end of the Great War up to 1926, whereas two banks had already existed in Vranje prior to that period: The Bank of Vranje and the Economic Bank of Vranje. ${ }^{13}$ The third monetary institution, The Market Loan and Savings Bank of Vranje, was established in Vranje in the circumstances of "the general stagnation and unemployment in all fields of economy, heavy debt, money deficiency and shortage of convenient loans, high prices, low production and decreased consumption". ${ }^{14}$ Notwithstanding the fact that the economy was in a poor condition, a number of 672 money bureaus were active in the SCS Kingdom at the end of 1926, which was six more than in the previous year. ${ }^{15}$

The financial and economic situation in the town of Vranje motivated the founders to establish the Market Bank. The financial crisis affected local craftsmen, merchants and all other owners of small businesses to such a degree that only substantial loans could give them some further support. Having progressed considerably after the war, the trading business was brought to a virtual standstill and depended on a temporary, and perhaps a long-term, support from money bureaus for duly payment of its obligations. The financial support was particularly necessary to those companies that had been recently established and to those that had started their business with little capital. It was the dawn of industrial production in Vranje, which consequently needed some financial support. The founders realized that they would benefit greatly from the establishment of a new bank. They believed that the new financial institution would not only be the epicentre of the capital, but that it would also gather considerable amounts of unengaged money, in the form of savings deposits, especially from the country population. The financial crisis would be thus alleviated, while substantial capital would contribute to the reduction of the number of usurers who used to lend money to individuals at exorbitant rates of interest. The already existing money bureaus managed to partially suppress the practice of usury, which was still present in Vranje and its vicinity. The ambitious founders of the Market Bank intended to triple the principal capital in the following two or three years, which would be extremely beneficial for the economy of this poor region. ${ }^{16}$

The Market Bank was founded upon the decree issued by the Ministry of Commerce and Industry on 26 May 1926. The call for the shares application, which was executed in the shops owned by Janče Dingarac and Radivoje Bogdanović, and for the Preliminary meeting of the shareholders was issued on 8 June. ${ }^{17}$ The founders were certain that they would register

13 The following banks were founded in Skoplje: Commercial and Trade Bank "Vardar", the Bank "Old Serbia", Export Bank, South Serbia Economic Bank and Export and Market Bank; the banks established in Gnjilane were the Economic Bank and the Bank "Novo Brdo"; Economic Bank was founded in Vranje, the Trade and Industrial Bank was established in Kumamovo, the Trade Bank "Ibar" was founded in Kosovska Mitrovica, the Credit Bank was founded in Vlasotince, the Market Bank was opened in Surdulica, the Kosovo Credit Bank was started in Priština, the Trade and Industrial Bank was opened in Tetovo, the Jablanica Credit Savings Bank was founded in Lebane (Gavrilović 1931: 80-84.).

AJ, 81-1-1, Banking and insurance.

16 AJ, 65-1460-2444, The plea of the founders of the Market Bank of Vranje to the Ministry of Commerce and Industry on 4 April 1926.

17 Službene novine Kraljevine Srba, Hrvata i Slovenaca, 8 June 1926, 12. 
and pay in the principal capital prior to the meeting scheduled for 12 July 1926; however, shortly after the announcement of the meeting date, some members of the Founding Committee of the Market Bank resigned. Namely, the owners of "Nova radnja", a shop that sold manufactured fashion clothes and fabric, Stojan Stefanović and Toma Ratajac, informed the Committee about their resignation from the membership in a letter on 16 June 1926. They stated that the main reason for their resignation from the Committee was their recent financial hardship and the ensuing inability to fulfill their obligations. ${ }^{18}$ Other members of the Founding Committee believed that the refusal of these two members to apply for shares had been induced by "certain interested individuals" who realized that the founding of a new money bureau in Vranje would endanger their financial status and position. The Founding Committee selected two new members so that the principal capital of one million dinars was paid in and after the deduction of the incurred expenses, the Market Bank had 866,499 dinars at its disposal. ${ }^{19}$

The founding capital of one million dinars was divided to 1,000 shares, each worth of 1,000 dinars. The high nominal value of shares showed that this venture had not been intended for a large number of shareholders, as was frequently the case, but for the respected and eminent shareholders, the businessmen who attempted to engage their capital in the time of general economic stagnation. This fact was confirmed by the first meeting of the shareholders, attended by only twelve shareholders who owned 270 shares. $^{20}$

The activities of the Market Bank included the following:

- discount of promissory notes, bills, payments, warrants, cheques, etc.;

- approval of loans to the owners of current accounts and cheque business;

- approval of loans secured by stocks, merchandise (the Lombard rate), and other various bonds and securities for the payment of a loan;

- various money transactions;

- safekeeping and safe deposit activities;

- savings and accumulation of money;

- approval of loans for the support of the tobacco production, wine growing and fruit growing in the town and its vicinity. ${ }^{21}$

The Board of Directors consisted of five members, whereas three shareholders were selected to be the members of the Supervisory Board. The profit earned by the Market Bank was divided in the following manner: $10 \%$ was paid in the reserve fund, up to $5 \%$ was set aside for cancelling uncollectible debts, $4 \%$ was paid in the retirement fund of the bank employees, $5 \%$ was paid in the fund for purchasing the bank building, $10 \%$ was paid as a share of profits to the members of the Board of Directors, $4 \%$ was paid as a share of profits to the members of the Supervisory Board, and, in accordance with the proposition of the Board of Directors, up to $6 \%$ was paid as a share of profits to the bank employees, corresponding to their salaries and

18 AJ, 65-1460-2444, The letter from the company "Nova radnja" sent to the Market Bank of Vranje on 16 June 1926.

19 AJ, 65-1460-2444, The plea of the founders of the Market Bank of Vranje to the Ministry of Commerce and Industry on 8 July 1926; The report of the Board of Directors of the Market Bank of Vranje presented at the Preliminary meeting of the shareholders on 12 July 1926.

20 AJ, 65-1460-2444, The list of the shareholders of the Market Bank of Vranje, present at the First meeting of the shareholders held on 23 January 1927.

${ }^{21}$ The Market Bank of Vranje Regulations 1926: 4-7. 
years of work experience in the year in which the profit was made. The Shareholders' Assembly handled the rest of the profit. ${ }^{22}$ It is evident that the calculated deductions from the profit were rather large and that the payment in dividends of $56 \%$ was much lower in comparison to the common practice of other money bureaus in the country. ${ }^{23}$ This is partially explained by the bank rules that defined the existence of as many as four funds, but, on the other hand, the shares of profits paid to the members of the Board of Directors and to the bank employees were considerably higher when compared to those in other banks. The greatest interest of the shareholders was evidently in the engagement of their capital.

The following were the founders of the Market Bank, all of them originating from Vranje: Janča Z. Dingarac, merchant; Zafir Čatlajac, merchant; Radivoje Z. Bogdanović, merchant; Toma Ratajac, merchant; Josif T. Vlajinac, merchant; Đorđe D. Džokić, innkeeper; Miloje Đorđević, baker; Stojan St. Stefanović, merchant; Velimir Ž. Damnjanović, bank clerk; Dragutin Ristić, carpenter; Božidar Đ. Zdravković, banker. After Stojan Stefanović and Toma Ratajac had resigned from the Founding Committee, the Minister of Commerce and Industry appointed Mihajlo Aleksić and Sava Stošić, tavernkeepers, in their place. ${ }^{24}$ The majority of the founders were merchants, as was quite common in most of the banks founded in the territory of Serbia at that time. The enterprising spirit of this class of entrepreneurs represented the driving force of Serbian economy. Moreover, they were motivated by their need to join the capital with the purpose of securing their positions on the market and acquiring desirable loans for their own wellbeing.

The first Board of Directors of the Market Bank consisted of the following shareholders: Janča Dingarac, Zafir Bogdanović, Nikola Vlajinac, Radivoje Bogdanović and Đorđe Džokić. The members of the Supervisory Board were Gradimir Bogdanović, Dragutin Ristić and Milan Bogdanović. ${ }^{25}$ The biggest shareholders were Janča Dingarac, possessing 180 shares, Zafir Čapkajac (Bogdanović) with 100 shares, Đorđe Džokić with 80 shares, Nikola Vlajinac with 68 shares and Milan Bogdanović who owned 65 shares. ${ }^{26}$ The family Bogdanović owned the largest number of shares and was therefore the most influential entity in the Market Bank. The official supervision conducted by the end of 1928 revealed that as many as six out of eight members of the bank management were either relatives or in-laws. Janča Z. Dingarac, the president of the Board of Directors, was the father-in-law of the vice president, Radivoje Z. Bogdanović, i.e. the vice president of the Board of Directors was the president's son-in-law. Zafir Bogdanović was the president's father and Kosta Bogdanović was the president's cousin. The president of the Supervisory Board, Zafir Bogdanović, was the son of the member of the Board of Directors, Kosta Bogdanović, whereas the member of the Supervisory Board, Milan Bogdanović, was the son of the member of the Board of Directors, Zafir Bogdanović. The only shareholders not

\footnotetext{
Ibid. 11-19.

23 The shareholders' assemblies commonly had $70 \%$ of the profit at their disposal, but this percentage was considerably higher in certain banks, such as the Market Bank of Vranje, where it was 85\% (Becić 2017: 111).

24 Ibid. 21-23.

25 AJ, 65-1460-2444, Minutes of the Preliminary meeting of the shareholders of the Market Bank of Vranje from 12 July 1926.

26 AJ, 65-1460-2444, The list of the shareholders attending the Preliminary meeting of the shareholders of the Market Bank of Vranje from 12 July 1926.
} 
related to the Bogdanović family were Dimitrije Z. Stojković, the member of the Board of Directors, and Relja Jančić, the member of the Supervisory Board. The fact that the Bank management was marked by nepotism was not seen as convenient, but it was not illegal. ${ }^{27}$

\section{The Activities of The Market Bank before The Great Depression}

The Market Bank of Vranje started to work in early August of 1926. Established at the time of economic distress, the Bank did not have much work in the beginning and became more profitable during November of the same year. Besides the economic crisis, the main reason for such a slow progress was the fact that the Bank, being a newly-founded financial institution, was not fully known in the vicinity of Vranje. The Market Bank was most successful regarding the savings deposits, which surpassed the principal bank capital in less than six months. The Bank management was at one point even concerned about the large inflow of money which they could not invest. Despite the real demand for loans, the Bank management was reluctant to approve them owing to unreliable and insufficient credit securities. Attempts were made to offer the money to other banks under favourable conditions, but it was not accepted since other banks also had considerable sums of money at their disposal. That the money bureaus owned considerable wealth they could not invest anywhere is proven by the fact that the Market Bank was approved 300,000 dinars of credit by the Yugoslav Bank from Belgrade immediately after it had started operating. ${ }^{28}$

The Bank management decided to invest part of its money into buying the bonds of the First World War reparations and purchased 600 bonds. By the end of that year, the management introduced the "progressively insuring savings", which the population accepted so well that the savings deposits increased. Thus, satisfied by this accomplishment, the Market Bank decided that the savings would be one of its main occupations. The profit earned in that manner, as well as the profit gained from the bonds, was included into the reserve fund. Similarly to the rest of the small money bureaus, the Market Bank was encumbered by high overheads, which had risen up to $30,177.05$ dinars in less than five months. The greatest expenses were incurred by purchasing new office stationery and various printed documents. The annual lease payment was 30,000 dinars, so the principal capital of the Bank had been initially decreased by about 100,000 dinars. In order to attract more clients, the Bank created a slight distinction between the passive and active interest rate, which was partially motivated by the business conduct of other money bureaus in Vranje. ${ }^{29}$

Numerous money bureaus in the SCS Kingdom were burdened by considerably high overheads. Therefore, in the course of 1926 and 1927, the idea of bank mergers dominated the banking sector with the purpose of lowering the expenses and providing advantageous loans for their clients. The passive interest rate fluctuated from $8 \%$ to $12 \%$ in 1927 , whereas the rise of the deposits, which showed a constant upward trend, was directly related to the economic crisis since businessmen hesitated to invest their capital and were more willing to

\footnotetext{
AJ, 65-1460-2444, The supervisory report on the Market Bank of Vranje from 31 December 1928.

28 AJ, 65-1460-2444, The report of the Board of Directors of the Market Bank of Vranje presented at the First regular meeting of the shareholders on 23 January 1927. AJ, 65-1460-2444, Ibid.
}

29 
secure its long-term engagement. ${ }^{30}$

The next meeting of the shareholders of the Market Bank was held in its own premises at $147 \mathrm{Kralj}$ Aleksandar street, the announcement of which had been issued a month prior to the meeting in accordance with the regulations..$^{31}$ The problem of money investment troubled all money bureaus in Vranje in 1927. Additional expenses were incurred by constantly increasing savings deposits so that the balance of the Market Bank decreased not before the end of that year. However, the Bank did not refuse future clients who deposited their money in order to keep its already widely known reputation. The Board of Directors of the Market Bank concluded that the crisis of money investment was caused by high interest rates, both the discount rates and the interest rates on savings deposits. Particularly problematic was a high passive interest rate, which was the highest in Vranje in comparison to the rest of Serbia, and definitely higher than the one granted by money bureaus operating in that region (in Kumanovo, Kosovska Mitrovica, Gnjilane). Accordingly, the discounted active interest rate could not be low, which meant that the Market Bank operated with a divergence of $1 \%$ to $2 \%$, or $5 \%$ at most. In order to lower the discounted interest rate, the Board of Directors tried to make an agreement with the representatives of other banks from Vranje about decreasing both interest rates by $3 \%$, but they had never managed to reach that agreement. Lowering of the interest rate was on the agenda of the Market Bank for the ensuing period. This could be accomplished only if supported by the National Bank and the Postal Savings Bank, which was planned to be attained during $1928 .^{32}$

The Market Bank bought additional 743 bonds of the First World War reparations, not just to invest its money into something but because it was considered to be a good business move. Although the interest rate of the bonds was not so high $(2.5 \%)$, their value kept growing and the profit was tax free. The Board of Directors explained that the reason why the Market Bank was involved in credit and banking activities exclusively lay in their strong belief that any individual or company had to do the work they were meant for: merchants should deal with trading, industrialists were expected to manage their industries, while bankers should be involved in banking. However, neither the management nor the employees of the Market Bank possessed enough knowledge related to the banking sector and securities of the banking activities, so there were certain complaints against several members of the staff. ${ }^{33}$

\footnotetext{
AJ, 81-1-1, Banking and securities.

Službene novine, 15 February 1928, 6.

AJ, 65-1460-2444, The report of the Board of Directors of the Market Bank of Vranje presented at the Second regular meeting of the shareholders held on 18 March 1928.

33 Clients mostly complained to the Ministry of Commerce and Industry about not being able to withdraw their total savings deposits in case of an emergency, but it was the client Dušan Dingarac who made the most serious complaint regarding the services of a bank cashier. Namely, he accused the cashier Božidar Zdravković of withdrawing the money from his own savings account without his knowledge, but with the knowledge of the Board of Directors. In his defense, Mr. Zdravković informed the Ministry that he had been granted an unwritten authority by Dušan Dingarac to withdraw the money with which to finance the construction of a toilet in the client's backyard. The Board of Directors confirmed that Mr. Dingarac used to come to the Bank in order to give certain professional instructions related to the digginig of the sewers, on which occasions he never expressed any disapproval or objections to the bank services. After this case, the Board of Directors realized the necessity of having the written authorities issued by their clients (AJ, 65-1460-2444, The complaint issued by Dušan Dingarac, an engineer, and sent to the Ministry of Commerce and Industry on 20 December 1927;
} 
The Board of Directors declined the share of profit pertaining to them for the year of 1927 in the interest of the shareholders, whereas the bank employees did the same since they received a total of thirteen salaries for that year. The Market Bank expanded its cooperation with other banks, so that, besides the Yugoslav Bank, it started cooperating with the Commercial and Industrial Bank "Vardar" from Skoplje, whose management was assiduously attentive and considerate towards the Market Bank throughout the whole year. ${ }^{34}$ Upon the proposition of Boža Zdravković, the total profit of 45,000 dinars gained in 1927 was included into the reserve fund. ${ }^{35}$

The emergency meeting of the Market Bank shareholders was called for 1 July 1928. The reasons were the alteration of the bank rules owing to the new measures introduced by the Ministry of Finance and the proposition of the Board of Directors about the enlargement of the principal bank capital. The decree issued by the Minister of Finance forbade state employees from being members of the managerial and supervisory boards of corporations and other limited liability companies. Therefore, Jovan Antić, a veterinarian, was forced to resign from the membership in the Board of Directors. Nikola T. Vlajinac also resigned from his engagement in the Board of Directors, stating that he was too involved in his other business enterprises to have enough time to participate in the activities of this board. He sold his shares on condition that the purchaser be appointed his position. ${ }^{36}$

The Board of Directors proposed that the Market Bank principal capital be enlarged to two million dinars since the previous amount had been insufficient for achieving a desirable profit. They also emphasized that this measure would decrease the overheads by $50 \%$ and would provide an opportunity for the bank to apply for loans granted by the state monetary institutions because it would fulfill the necessary conditions. ${ }^{37}$ The decision on the principal bank capital enlargement was unanimous. ${ }^{38}$

The results that the Market Bank achieved in 1928 were better than those in the previous years. The investment crisis still lasted and the Bank management tried to avoid the rise of the savings deposits and thus the increase of the discount, which was an indication that the portfolio was liquid. The Bank had enough finances to use the approved loans. The loans were taken by merchants, craftsmen and farmers, the main securities being promissory notes, mortgages and current accounts. The profit of the Market Bank was 65,835 dinars, and the shareholders had at their disposal the sum of 45,000 dinars. It was possible to grant this percentage out of the total profit because the Board of Directors renounced their right to the shares of profit once again, as well as the bank employees, who again received thirteen salaries

The reply of the Board of Directors of the Market Bank of Vranje sent to the Ministry of Commerce and Industry on 27 October 1928).

34 AJ, 65-1460-2444, Ibid.

35 AJ, 65-1460-2444, Minutes of the Second regular meeting of the shareholders of the Market Bank of Vranje from 18 March 1928.

36 AJ, 65-1460-2444, The report of the Board of Directors of the Market Bank of Vranje presented at the Emergency meeting of the shareholders held on 1 July 1928.

37 In order to encourage the bank mergers in 1927, the National Bank decided to approve loans to the banks in provincial parts of the country only in case their principal capital was at least one million dinars. In the towns with more than five banks (like Vranje), the principal capital required was at least two million dinars (Becić 2015: 64).

38 AJ, 65-1460-2444, Minutes from the Emergency meeting of the shareholders of the Market Bank of Vranje from 1 July 1928. 
during that year. The Bank Assembly decided that the money be added to the reserve fund. ${ }^{39}$

The opinion expressed by the supervising bodies appointed by the Ministry of Commerce and Industry was completely different from the positive reports presented by the Board of Directors and related to the activities of the Market Bank. Similarly to the majority of the managerial boards of other money bureaus, the Board of Directors of the Market Bank was assessed as unprofessional since the members of this board were not the individuals professionally involved in the banking sector, but those included in other fields of economy. Neither the members of the Board of Directors nor the cashiers knew with certainty how much effective money was registered either in the daily cash book or in the main cash book, which all hindered the verification of the actual financial state. The Bank had already possessed the protest bonds, whose value was 601,061 dinars, which were not submitted to court but were kept in lawyers' offices. Moreover, the Bank had the promissory notes worth 191,912 dinars, whose expiry date had long passed and whose liquidity was thus insecure. The Market Bank was therefore burdened by the sum of 792,973 dinars which, together with the promissory notes of the Industrial and Commercial Bank Ltd. from Vranje amounting to 100,000 dinars and being due for payment on 6 January 1929, seriously impaired the credit liability and the liquidity of the Bank. Hence, the Market Bank was forced to have the provisions of the credits worth over two million dinars approved by the Bosnian Bank and by other money bureaus, whereas the state of the portfolio represented a great risk for the security of the savings deposits. ${ }^{40}$

The Board of Directors declared that the year of 1929, unlike the previous ones, was very successful since the economic situation in the country improved. The principal capital had already been partially paid in since both the nominal value and the leverage variance were paid, while the total amount of the principal capital was paid in May of 1930. The year of 1929 witnessed a change in the previous business trend in relation to the discount and current account. The dominant discounted cash transfer was lowered, but the current account cash transfers increased by 636,876 dinars in comparison to the previous year. The Board of Directors declined their right to the shares of profit, but they were paid to the bank employees. ${ }^{41}$ The total profit was 101,900 dinars, while the shareholders' shares of profit were $7 \%{ }^{42}$ The Shareholders' Assembly held in early 1930 decided to revoke the fund for purchasing the bank building and the fund for cancelling uncollectible debts as unnecessary since the reserve fund was the provision against potential losses. ${ }^{43}$

\section{The Market Bank during The Crisis}

The Great Depression had a detrimental effect on the enthusiasm and successful

39 AJ, 65-1460-2444, The report of the Board of Directors of the Market Bank of Vranje presented at the Third regular meeting of the shareholders on 10 March 1929.

40 AJ, 65-1460-2444, The supervisory report on the activities of the Market Bank from 31 December 1928.

41 AJ, 65-1460-2444, The report of the Board of Directors of the Market Bank presented at the Fourth regular meeting of the shareholders on 9 February 1930.

42 Compass 1931:422.

43 AJ, 65-1460-2444, The report of the Board of Directors of the Market Bank of Vranje presented at the Fourth regular meeting of the shareholders on 9 February 1930. 
business of the banks in the Kingdom of Yugoslavia. This severe economic depression, which first began in the USA in October of 1929, took place in Europe mostly during the 1930s, but did not affect the Yugoslav economy at its start. Namely, being a predominantly agricultural country with an abundance of resources used mainly as half-products, Yugoslavia was not so deeply affected in those early days of this economic depression. ${ }^{44}$ However, the crash of the Viennese banking giant, Kreditanstalt, led to the withdrawal of its capital investments from the money bureaus in Slovenia, Croatia and Vojvodina in May of 1931. The abortion of the foreign loans had as its consequence the retraction of the inactive credits granted to the money bureaus by the National Bank and the request that the approved loans be urgently paid off. A sudden money deficiency caused panic among the investors and the withdrawal of savings deposits from banks in the early autumn. It was estimated that out of the total amount of the money withdrawn in October 1931, a sum of 750 million dinars was stocked and stored, so that the lower money supply induced another rise of interest rates, which ranged from $16 \%$ to $24 \% .{ }^{45}$

Large payments from savings deposits affected the banking sector considerably since the withdrawn money was not available for a longer period of time. "Clients swarm into the bank bureaus out of the fear of the banks insolvency. The fear of devalorization of money induces people to buy gold or foreign currencies or real estates. No fear is so great as the capitalist fear of losses. It occasionally grows so intense and unreasonable that it accelerates what was allegedly expected to have been avoided. It is precisely owing to that fear that even certain temporary hardships of the credit and monetary system of one country are easily transformed into severe and serious crises". ${ }^{46}$

Farmers' complaints against the banks' requests for clearing all the debts and their inability to fulfill that request resulted in the moratorium on the liquidation of the farmers' debts on 19 April 1932. This government measure was aimed at protecting this most numerous class of inhabitants. However, although this motion on the protection of farmers presupposed also the protection of those money bureaus whose liquidity was jeopardized, it actually paralyzed the activities of the banks. Money bureaus were mainly involved in collecting the means by retrieving the money for compensating the creditors. The investors had already become accustomed to banks being non-liquid and to being paid out only small amounts of money. ${ }^{47}$ Yet, the Yugoslav money bureaus managed to pay off four and a half billion dinars of savings deposits in a comparatively short period of time. Therefore, they too had to be protected because otherwise, they would have had to pay off additional ten and a half billion dinars, which would lead to a total collapse of the private banking sector. ${ }^{48}$

Before the Great Depression started, the Market Bank had been exclusively involved in approving short-term loans to farmers, merchants and clerks, secured by promissory notes, mortgages and intabulation. The Bank had been profitable up to the introduction of the moratorium, which created difficulties for the Bank in charging the farmers' debts since they refused to pay them off despite very favourable conditions granted by the law. The

44 Đurović 1986: 104.

45 Politika, 3 March 1932, 4.

46 Politika, 27 September 1931, 2.

AJ,74-86-127, General review of the economic situation in the country from 8 May 1933, 1-2.

48 AJ, 38-577-744, "Our finances in 1932: a special review of the situation in Vojvodina”, Obzor, 14 January 1933. 
Bank encountered trouble regarding the merchants' promissory notes, partly due to a general economic crisis and partly because the merchants took the advantage of the Land Tenure Policy from 4 January 1933, according to which the Bank was not allowed to charge the debts for nine months of the intermediation period. The main creditors and investors grew impatient because of partial payments they received, so they started law suits against the Market Bank, thus worsening its already unenviable position. ${ }^{49}$

Financial difficulties led to unpopular measures of the confiscation of property owned by defaulters and clients, but they also provoked certain individuals to demand the disbursement from the Market Bank regardless of the circumstances. Insufficient knowledge of the laws and regulations involved the Market Bank into a trial that even the Ministry of Finance got interested in. Namely, the Market Bank concluded that the moratorium for the protection of farmers did not apply to the endorsers who were entrepreneurs in service business or some other businesses and it consequently distrained their property. However, according to the law, all the endorsers to the farmers no matter their occupation were protected from the practice of legal seizing of property in the default of payment. Both the aggrieved parties and the Market Bank issued complaints, which only prolonged the trial. ${ }^{50}$ The Market Bank complained about the behaviour of some of its clients who, regardless of their ample profit from the savings deposits in the past, now pressed the Bank to pay off the total amounts of their savings, notwithstanding the gravity of the crisis that affected the Bank. ${ }^{51}$

In the course of the first two years of the moratorium, the Market Bank paid off 2,700,000 dinars of savings deposits, which emptied its reserve fund almost completely. It though held no debts to the state money bureaus, except for the debt it owed to the Industrial and Commercial Bank "Vardar" which amounted to 50,000 dinars. Realizing that it could no longer accomplish its duties, the Market Bank held the shareholders' meeting on 25 March 1924 and decided to request the postponement of payment in accordance with the Decree on the protection of monetary institutes and their creditors passed on 4 December 1933. This request was a clear indication that the economic crisis had reached its peak in Vranje, because two local banks had already been under liquidation whereas one was under protection. $^{52}$

The payment agenda of the Market Bank shows that it intended to pay off $3 \%$ of the

49 AJ, 65-1460-2444, The plea of the Market Bank of Vranje sent to the Ministry of Commerce and Industry on 9 July 1934.

50 This refers to the case implicating Vojislav Cvetković, a grocer from Vranjska Banja, which started in the middle of 1932 and continued even during 1933 (AJ, 65-1460-2444, The decree of the Prefecture of the District of Pčinje from 13 July 1932.).

51 The Market Bank complained to the Ministry of Commerce and Industry about the behaviour of one of its clients, Mr. Pavlović. The Bank emphasized that this client had deposited 90,000 dinars in 1926 and that he had withdrawn a sum of 147,000 dinars until 9 July 1934, whereas he still had 12,522 dinars in his bank account. It was estimated that his profit from the interest rate was 57,000 dinars. This client had savings accounts in other banks as well, which he had already withdrawn. Therefore, the Board of Directors of the Market Bank considered that such a pressure coming from Mr. Pavlović and other clients was the reason enough for starting a procedure aimed at receiving protection (AJ, 65-1460-2444, A written account of the Market bank of Vranje sent to the Ministry of Commerce and Industry, undated).

52 AJ, 65-1460-2444, Ibid. 
annual interest rate and 3\% of the interest rate on the principal amount of the debt. Higher interest rates were not acceptable since the Bank had no profitable transactions and its greatest defaulters were farmers. In the first trimester of 1934, the Market Bank settled the promissory notes amounting to 100,000 dinars. The Bank endorsed the promissory note for the Electric Company of Vranje in the amount of 740,000 dinars, whereas this company, acting as an acceptor and using the endorsement of its members of the Board of Directors and Supervisory Board, supplied the Bank with the counter promissory note on account of their giro account. The Market Bank considered the Electric Company of Vranje to be very reliable because its members were the most distinguished citizens of Vranje. Since the Electric Company needed a loan urgently, it endorsed its promissory notes in the National Bank, the Credit Bank of Vranje and the Economic Bank of Vranje. ${ }^{53}$

\begin{tabular}{|c|c|c|c|c|}
\hline Year & Capital & $\begin{array}{c}\text { Discount } \\
\text { of promissory notes }\end{array}$ & Reserve fund & Savings deposits \\
\hline 1926 & $1,000,000$ & $1,817,900.00$ & $23,458.50$ & $1,274,163.90$ \\
\hline 1927 & $1,000,000$ & $4,859,832.00$ & $63,895.13$ & $3,985,553.50$ \\
\hline 1928 & $1,000,000$ & $4,210,580.00$ & $108,953.13$ & $3,473,272.00$ \\
\hline 1929 & $1,000,000$ & $3,966,218.00$ & $346,000.00$ & $3,855,010.74$ \\
\hline 1930 & $2,000,000$ & $4,259,245.00$ & $354,175.00$ & $4,273,702.00$ \\
\hline 7 July 1934 & $2,000,000$ & $3,146,797$ & $48,322.67$ & $1,694,240.00$ \\
\hline 1935 & $2,000,000$ & $2,983,641.73$ & - & $1,486,161.00$ \\
\hline 1 March 1941 & $2,000,000$ & $1,387,895.48$ & - & $886,795.00$ \\
\hline
\end{tabular}

Table 1. The balance of the Market Bank of Vranje (in dinars) ${ }^{54}$

The intabulations of the farmers' promissory notes amounted to 402,225 dinars and the notes recorded in writing secured additional 261,400 dinars. As regards the nonmoratorium demands, the intabulations amounted to 428,310 dinars and written notes were 599, 156 dinars. ${ }^{55}$ The report issued by the representatives of the Ministry of Commerce and Industry stated that the total of the moratorium demand payments of the Market Bank amounted to $1,836,725$ dinars or $47 \%$ of the total demand. The amount of 663,625 dinars or $36 \%$ of the demand payments were secured (intabulations and written notes). The nonmoratorium demand payments amounted to 2,051,458 dinars and were secured by $1,027,466$ dinars or $50 \%$. The mortgages provided securities for all the obligations of the Bank towards its investors and creditors. Since this monetary institution was liquid and active, the thorough review of the Ministry supervisors was not indispensable. According to the Articles 22 and 66 of the Decree on protection of monetary institutes and their creditors, the Market Bank was granted protection and postponement of payment for the period of six years. The gross annual interest rate on savings deposits and current accounts

53 AJ, 65-1460-2444, The payment schedule.

54 AJ, 65-1460-2444, The balance accounts of the Market Bank of Vranje for the period from 1926 to 1941; Compass 1932: 416.

55 AJ, 65-1460-2444, The report presented on 9 July 1934. 
was $2 \%$ and the protection was applied on 1 January $1935 .{ }^{56}$ Zdravko A. Maričić was appointed the first commissioner of the Ministry of Commerce and Industry. ${ }^{57}$

\begin{tabular}{|c|c|}
\hline up to 1,000 dinars & 95 \\
\hline $1,000-10,000$ & 77 \\
\hline over 10,000 & 39 \\
\hline
\end{tabular}

Table 2. Savings deposits and current accounts deposits in the Market Bank on 31 December $1935^{58}$

The total debt of the Market Bank accounting savings deposits and current accounts was $1,486,161$ dinars. Although the majority of clients were those with deposits of 1,000 dinars, the debt towards them was merely $24,470.50$ dinars, which means that the average amount of their deposit was a modest sum of 257.58 dinars. The deposits of 10,000 dinars demanded a payment of 349,661 dinars, i.e. 4,541.05 dinars on average, whereas the payment for the savings deposits surmounting to 10,000 dinars were $1,112,027.50$ dinars, i.e. $28,513.53$ dinars on average. ${ }^{59}$

During the first year of the granted protection, the Market Bank paid off the deposits of 15,600 dinars, while the amount of 38,596 dinars was provided for the first six months of 1936. The clients with the deposits smaller than 10,000 dinars obtained $10 \%$ of the deposit, those with the middle-value deposits obtained $4 \%$ of the deposit, while the clients with the largest deposits were granted $2 \% .{ }^{60}$ The Market Bank was frequently unable to pay off the debts that became due for payment because of the inability to secure the necessary money supply. The insufficient funds for paying off interest rates, as well as the unexpected costs incurred by the transfer of the farmers' promissory notes and other documents to the Privileged Agrarian Bank all contributed to the Market Bank not being able to settle all of its agreements and obligations due for the first six months of 1937, the practice which repeated in the same periods during the following two years. ${ }^{61}$

Shortly before the breakout of the Second World War in the territory of the Kingdom of Yugoslavia, the debt of the Market Bank of Vranje owed to the Privileged Agrarian Bank for the farmers' promissory notes amounted to 523,408.75 dinars. The Bank management tried to lower this debt by means of the credit notes for the liquidation of the farmers' debts, which was seen as an opportunity to clear the default. This measure yielded no significant results because a small number of investors accepted it in the belief that it was better to occasionally receive the payments from the bank itself than to trade in credit notes on the

\footnotetext{
Službene novine Kraljevine Jugoslavije, 17 July 1935, 8.

57 AJ, 65-1460-2444, The Market Loan and Savings Bank of Vranje, shareholding bank, the report presented on 21 March 1935.

58 AJ, 65-1460-2444, The written account of the Market Bank of Vranje sent to the Minister of Commerce and Industry on 17 January 1936.

59 AJ, 65-1460-2444, The written account of the Market Bank of Vranje sent to the Minister of Commerce and Industry on 17 January 1936.

60 AJ, 65-1460-2444, Ibid.

61 AJ, 65-1460-2444, The pleas of the Market Bank of Vranje sent to the Ministry of Commerce and Industry from 15 April 1937 to 22 August 1939.
} 
market. ${ }^{62}$ The beginning of the Second World War disabled the Market Bank from pursuing the payment of the promissory notes from the Privileged Agrarian Bank, which actually meant the termination of its business.

The procedure for the liquidation of the Market Bank of Vranje was started on 7 October 1946, at the time when it did not function and was still under protection. The members of the Liquidation Board were Rista Simonović, a judge of the Basic Court, Dragutin Negrojević, employee of the financial department of SNO, and Milan Peić, barber. ${ }^{63}$ The Bank was officially liquidated in 1947.

\section{Conclusion}

A large number of small, local money bureaus were active in the territory of the Kingdom of Serbia and later of the Kingdom of Yugoslavia. They were established with the purpose of providing the necessary capital and profit for their shareholders, but also as a safe place for securing that profit and capital in the times of economic depression. The Market Bank of Vranje was founded during the time of a serious crisis in the money supply. Therefore, it is an illustrative example of a money bureau which won its place on the money market in that period of monetary crisis.

The economic crisis, which began in 1925, soon transformed the credit crisis into the crisis of the placement of finances and funds. The entrepreneurs believed that one of the solutions to that problem would be to invest their capital into the banking sector, which was done by the shareholders of the Market Bank of Vranje in 1926. Although the Bank had a modest amount of the principal capital, it was profitable and managed to pay the dividends to its shareholders and enlarge its principal capital in 1929.

The lasting economic crisis led to the increase of other parties' savings deposits and current accounts deposits, whereas farmers became the main loan borrowers. The success of the Market Bank of Vranje was hindered by the Great Depression, whose full effects were felt in the Kingdom of Yugoslavia in the second half of 1931, where the agrarian crisis had gradually transformed into the banking crisis. The withdrawal of large amounts of money and their stocking left money bureaus almost destitute since the majority of them could not fulfill their agreements and obligations towards clients. The banks were additionally encumbered by the moratorium on the farmers' loans, because it deprived them of the possibility to execute the majority of their accounts receivable. Therefore, the banks themselves were forced to seek protection. In accordance with the Decree on protection of monetary institutes and their creditors, the Market Bank of Vranje was placed under protection in 1935.

It actually meant that the Bank was authorized only to receive the farmers' promissory notes from the Privileged Agrarian Bank and to pay off its clients with the money obtained in that way. This one and only activity of the Market Bank of Vranje was terminated by the breakout of the Second World War in the territory of Yugoslavia in 1941. The Market Bank was liquidated after the Second World War, at the time when the newly

62 AJ, 65-1460-2444, The plea of the Market Bank of Vranje sent to the Ministry of Commerce and Industry on 15 March 1941.

63 AJ, 12-588-61, The Decree of the Federal Ministry of Finance from 7 October 1946. 
established government of the Socialist Republic of Yugoslavia prohibited the activities of any privately-owned monetary institutions.

\section{REFERENCES:}

Unpublished sources:

Archives of Yugoslavia, Belgrade (=AJ)

The Anthology of Dobrivoje Stošović (=81).

The Archival fund of the Central Press Bureau of the Presidency of the Ministerial Council of the Kingdom of Yugoslavia (=38).

The Archival fund of the Royal Palace of Serbia (=74).

The Archival fund of the Ministry of Commerce and Industry of the Kingdom of Yugoslavia (=65).

The Archival fund of the Ministry of Finance of the Federal People's Republic of Yugoslavia (=12)

Published sources:

Compass, Finanziellesjahrbuch 1931, Jugoslavien, Wien 1931.

Compass, Finanziellesjahrbuch 1932, Jugoslavien, Wien 1932.

Kraljevina Srba, Hrvata i Slovenaca, Almanah 1921-1922, Zagreb 1922.

Pravila Vranjske prometne banke za Kredit i Štednju a. d. u Vranju, Vranje 1926 (Serbian Cyrillic).

Službene novine Kraljevine Srba, Hrvata i Slovenaca (1926-1928), Beograd (Serbian Cyrillic).

Službene novine Kraljevine Jugoslavije (1935), Beograd.

Newspapers and publications:

Bankarstvo (1926), Beograd (Serbian Cyrillic).

Ekonomist (1926), Beograd (Serbian Cyrillic).

Jugoslovenski Lloyd (1924), Zagreb.

Narodna Sloga (1924), Pančevo (Serbian Cyrillic).

Narodno blagostanje (1931), Beograd (Serbian Cyrillic).

Politika (1931-1932), Beograd (Serbian Cyrillic).

Samouprava (1923), Beograd (Serbian Cyrillic).

\section{References:}

Belin, I. Problemi naše valute, studija za sanaciju naše privredne krize, Zagreb: Nova Evropa, 1924.

Becić I. M. 'Čačanska oblasna banka', Zbornik radova Narodnog muzeja, XLV, 2015, $61-73$ (Serbian Cyrillic).

. 'Vranjska banka u Kraljevini Jugoslaviji', Godišnjak Pedagoškog fakulteta u Vranju, 2017, 109-122 (Serbian Cyrillic).

Đurović, S. (1986). Državna intervencija u industriji Jugoslavije (1918-1941), Beograd: Institut za savremenu istoriju.

Gavrilović M. R. Razvoj bankarstva i privrede u Južnoj Srbiji, Skoplje: Krajinčanac, 1931 (Serbian Cyrillic).

. Ministarstvo finansija Kraljevine Jugoslavije1918-1938, Beograd: Ministarstvo finansija, 1938 (Serbian Cyrillic).

. Narodna banka 1884-1934, Beograd: Narodna banka Kraljevine Jugoslavije, 1934 (Serbian Cyrillic).

Petranović, B. Istorija Jugoslavije 1918-1988, I. Beograd: Nolit, 1988.

Popović B.- Mišić D. Naša domaća privreda, faktori, stanje-unapređenje, Beograd: Geca Kon, 1929 (Serbian Cyrillic). 


\author{
ДЕЈАН Д АНТИЋ \\ Универзитет у Нишу, Филозофски факултет
}

ИВАН М. БЕЦИТ

Институт за српску културу - Приштина, Лепосавић

ВРАњСКА ПРОМЕТНА БАНКА ЗА КРЕДИТ И ШТЕДЫУ: 1926-1947.

\title{
Резиме
}

Хроничан недостатак кредита у првим послератним годинама подстакао је оснивање новчаних завода на читавој територији Краљевине СХС. По већ устаљеној традицији, највећи број банака са невеликим капиталом пословао је на простору предратне Краљевине Србије и Црне Горе. Привредна криза, која је отпочела 1925. године кредитну кризу претворила се у кризу пласмана средстава. Као једно од решења како упослити сопствени капитал, поједини привредници видели су у томе да га пласирају у банкарство, што су учинили и акционари Врањске прометне банке 1926. године. Иако је располагала са скромним капиталом, Прометна банка бележила је добит, а током 1929. године својим акционарима је исплатила дивиденду и извршила повећање основног капитала.

Трајање кризе изазвало је пораст туђих средстава у банкама по улозима на штедњу и текућим рачунима, док су главни клијенти кредита постајали земљорадници. Успешан рад Прометне банке прекинуле су последице Велике економске кризе, које су се у Краљевини Југославији осетиле од половине 1931. године и уз аграрну, узеле облик и банкарске кризе. Повлачење новчаних средстава и њихово тезаурисање оставили су новчане заводе на несигурним ногама и многи од њих нису били у могућности да одговоре потраживањима. Мораторијум на отплату земљорадничких дугова додатно је оптеретио банке, јер их је оставио без могућности да наплате највећи део својих потраживања. Банке су биле принуђене да и саме потраже заштиту, а Врањска прометна банка стављена је под заштиту новчаних завода и њихових веровника од 1935. године.

У пракси је то значило да се њена активност сводила на примање принадлежности од Привилеговане аграрне банке по предатим земљорадничким меницама и исплату, тим новцем, својих штедиша. Ову, једину активност Прометне банке, прекинуло је избијање Другог светског рата на простору Југославије 1941. године. Званична ликвидација ове установе извршена је 1947. године.

Кључне речи: Врањска прометна банка, улози на штедњу, криза поверења, мораторијум, заштита новчаних завода.

(C) Faculty of Philosophy, Novi Sad, 2019

ISTRAŽIVANJA - JOURNAL OF HISTORICAL RESEARCHES 30, 217-233 